\title{
Fotograficidade: A Paisagem Humana no Imaginário Poético do Círio de Nazaré em Belém do Pará - Brasil
}

\section{Photographicity: The Human Landscape in the Poetic Imaginaire of Círio de Nazaré in Belém do Pará - Brazil}

\author{
Raimundo Freitas Aragão ${ }^{1}$ \\ Christian Dennys Monteiro de Oliveira ${ }^{2}$ \\ Tiago Vieira Cavalcante ${ }^{3}$
}

Palavras-chave:
Fotograficidade
Círio de Nazaré
Poesia
Geograficidade
Fotografia humanista

Keywords:

Photographicity

Círio de Nazaré

Poetry

Geographicity

Humanist photography

\begin{abstract}
Resumo
Fotograficidade é, aproximando-se da fotografia humanista, a geograficidade em imagens poéticas, os fotopoemas. Os palcos para este ensaio são as encenações e performances dos festejos do Círio de Nazaré em Belém do Pará. Para identificar e tornar real essa fotograficidade, abordamos, primeiro, o desenvolvimento da fotografia humanista como inspiração. Segundo, lidamos com a geograficidade ou a singularidade da vida humana em relação ao modo de existência espacial a partir de suas práticas sociais. Por fim, recorremos à poesia a partir do imaginário poético estetizante amazônico por meio do conceito de conversão semiótica, entendida como a mudança de qualidade simbólica no contexto cultural. Metodologicamente, a fotograficidade do Círio de Nazaré será construída no cruzamento entre a fotografia humanista, a geograficidade e a poesia. A partir desse cruzamento, objetivamos expandir e incentivar análises geográficas nas paisagens humanas.
\end{abstract}

\begin{abstract}
Photographicity is, resembling humanist photography, geographicity in poetic images, photopoems. The stages for this essay are the enactments and performances of Círio de Nazaré festivities in Belém do Pará. In order to identify and make this photographicity real, we first focus on the development of humanist photography as inspiration. Second, we deal with the geographicity or the singularity of human life in relation to the mode of spatial existence based on social practices. Finally, we turn to poetry from the Amazonian aesthetic poetic imaginaire through the concept of semiotic conversion understood as the symbolic change in the cultural context. Methodologically, the photographicity of Círio de Nazaré will be built on the intersection of humanistic photography, geographicity and poetry. From this intersection, the objective is to expand and encourage humanist geographical analyses in human landscapes.
\end{abstract}




\section{INTRODUÇÃO}

Ao se fotografar um determinado evento, notamos quão expressivos e dinâmicos são seus movimentos. Isso porque a fotografia, apesar de nos revelar um cenário e um momento, nos insta a imaginarmos paisagens e instantes de um devir iminente. A fotografia, portanto, não é propriamente a imagem congelada de um espaço-tempo; ela é também movimento.

Uma festa religiosa, por exemplo, potencializa esses movimentos. $\mathrm{O}$ religioso parece enquadrar cada vez mais performances, ritos, cenários piedosos e carnavalescos em um mesmo espaço-tempo, haja vista sagrado e profano, desde origens remotas, atuarem em comum acordo. São as novas ordens do simbólico, cunhadas ao momento em que novas paisagens vão sendo criadas ou readaptadas. $\mathrm{O}$ Círio de Nazaré, na metrópole de Belém, é uma experiência fantástica para o geógrafo-fotógrafo, sujeito aqui denominado por nós como fotogeógrafo, pois concordamos com Reis Junior (2014), quando este escreve que o fotogeógrafo, mesmo podendo não ser um geógrafo profissional, contribui com a ciência da paisagem e aquilo que ela demonstra das relações estabelecidas entre a natureza e a cultura.

Belém, a capital do estado do Pará, fundada em 12 de janeiro de 1626, tornou-se uma das mais importantes e expressivas hierometrópolis brasileiras - para reler na escala metropolitana o termo desenvolvido por Rosendahl (1999) construída sob os simbolismos e imaginários em torno da mítica figura cristã do catolicismo, Nossa Senhora de Nazaré. Desde os primórdios do surgimento da referida Maria, em 1793, constroem-se sobre a cidade relações de pertencimentos religiosos únicos referenciados por numerosas obras como, por exemplo, as de Alves (1980; 2005) ao caracterizar o Círio como uma densa fusão entre fé, carnaval devoto, dramaticidade, alegria e aguçados sentimentos durante os festejos. A estrutura e a organização urbanas onde se desenrolam as performances dos festejos são claramente dependentes dos simbolismos e dos imaginários os quais lhe dão suporte. Não há organização e dinâmica do religioso na cultura cidade sem essa pulsão advinda de uma forma utópica, seja ela visionária ou espiritual.

A convivência com essa ambiência, mesmo que em breve permanência com os festejos e a vida religiosa da cidade, permite observar não só os fiéis na busca de seu mundo particular, concreto, como também testemunhar o seu desejo de alcançar o mundo suprassensível, o mundo das figuras celestes. Por isso, na metrópole Belém e em suas ruas, onde os percursos disseminam as diversas encenações em torno do sagrado, a mística religiosa se renova projetando, nas imagens do Círio, a essência devocional de seu povo.

No contexto do alcance desse mundo concreto, e simultaneamente imaginal, a fotograficidade será construída metodologicamente na triangulação entre a fotografia humanista, a geograficidade dardeliana (2011) e o imaginário poético estetizante, considerando como ponto de partida o conceito de conversão semiótica de João de Jesus Paes Loureiro (2015). Todavia, apesar do neologismo fotograficidade, não se pretende apresentar resultados epistemológicos. Propõese, logo, a partir desse cruzamento, levantar reflexões sobre a importância do espaço geográfico em suas diversas formas aparentes, enquanto tudo isso surge aos nossos olhos antes, durante e depois que o fotogeógrafo aciona a sua máquina fotográfica.

As fotografias e suas imagens, as quais manteremos em preto e branco, em atenção ao período monocromático representativo da fotografia humanista, serão o nosso suporte documental. Quando capturadas em sua autenticidade constituem elementos primários da pesquisa. Ou seja, elas instrumentalizam a percepção, a compreensão e a reflexão geográfica, pois conectam produção de ideias, conforme argumentam Gomes e Ribeiro (2013). É nesse sentido, de um agrupamento metodológico de ideias, que a fotograficidade toma corpo, propensa em mostrar uma forma de inteligibilidade multidisciplinar, representativa da organização do espaço geográfico, ou melhor, dos sujeitos no espaço, construindo-o de forma ativa.

A fotograficidade, neste ensaio, compreende uma metodologia de acesso aos festejos do Círio de Nazaré como uma paisagem humana integral. Seus procedimentos envolvem elementos culturais em suas permanências, transformações e adaptações plenas de humanismo, daí a estratégia de entrecruzamento da fotografia humanista, da geograficidade e da poesia. O Círio de Nazaré é poesia em movimento e geografia em ato, que se move entre dois mundos: o terreno e o imaginal.

Temos assim a primeira parte deste ensaio, em que colocamos em evidência os caminhos a serem percorridos. $\mathrm{Na}$ segunda parte, aproximamos a fotografia humanista da noção geograficidade, no que elas têm em comum. Em seguida, apresentamos a ideia central de fotograficidade, a maneira como foi pensada e constituída, a partir de imagens e do imaginário 
sobre o Círio de Nazaré. E por fim, apresentamos nossas considerações finais.

\section{A fotografia humanista e algumas aproximações com a geograficidade}

(...) os fotógrafos humanistas, que tinham Paris como epicentro criativo, exaltaram a vida - e a paz -, produzindo imagens de anônimos do cotidiano urbano. As fotos estavam mais próximas de capturar a essência humana do que as imagens objetivas da imprensa (AVANCINI, 2011, p. 58).

A epígrafe acima abre os caminhos para aproximações. Pensamos haver convergências entre a fotografia humanista e a geograficidade, pois se vê nelas uma síntese fenomenológica da essência humana em sua existência espacial, com a exaltação à vida territorializada no espaço. Fotografia humanista e geograficidade tratam das mesmas coisas, pois têm como objetivo central o ser humano e suas relações com o ambiente em que vive. Para Holzer (2016), por exemplo, a geograficidade tem uma ligação direta com o cotidiano, do mesmo modo, a nosso ver, que as preocupações que tinham os fotógrafos humanistas.

Considerada uma corrente fotográfica, a fotografia humanista teve sua gênese nos anos de 1930 na França, especificamente na cidade de Paris. Seu auge ocorreu entre os anos de 1945 e 1950, estendendo-se aos anos de 1960. Recebeu essa denominação pela sua forte e incontestável inclinação à pessoa humana tanto no quadro profissional quanto no afetivo. Todos seus representantes partilhavam uma visão essencialista e lírica do homem e apoiavam-se sobre a ideia da natureza humana universal (MAILLET; DENOYELLE; VERSAVEL, 2006).

Régis Debray (1993) assevera que essa corrente foi ostensivamente francesa e parisiense e contribuiu para a construção de uma iconografia nacional. O que os fotógrafos humanistas tinham em comum era o interesse pelo ser humano imerso em sua vida habitual, como já destacado. Capturavam-se cenas da vida das pessoas comuns, tanto em suas existências simples, repletas de alegrias quanto de dificuldades e injustiças advindas dos problemas econômicos; daí tê-la, por exemplo, como reação às atrocidades dos anos de guerra. Outra proximidade que deve ser considerada é a de que a publicação de $O$ Homem e a Terra, do geógrafo Eric Dardel (2011), obra de grande relevância para a geografia humanista, ocorreu após a Segunda Guerra Mundial, momento do apogeu da fotografia humanista.

Ainda, para Debray (1993), praticava-se uma etnografia nacional ou uma antropologia de proximidade cujo enfoque era a vida social do sujeito. Os seres humanos considerados invisíveis, os trabalhos e seu cotidiano, os rituais, os festejos das tradições culturais, manifestações políticas, figuras e casais pitorescos, retratos de artistas e intelectuais (Figura 1) eram introduzidos (AVANCINI, 2011). Nesse contexto, se o centro de atenção da fotografia humanista era a pessoa em seu ambiente, o foco particularmente recaía sobre os mais desfavorecidos, esclarece Paviot (2019).

Há de se pensar, portanto, se a fotografia humanista não seria uma maneira de revelar geograficidades por meio da imagem e mesmo do imaginário que a imagem comporta, por aprofundar a existência do ser-no-mundo, “(...) partindo do postulado de que a unidade lógica da existência não é espaço, nem tempo, nem sociedade; é a pessoa humana, é o indivíduo tomado em sua relação fenomenológica com o mundo" (LÉVY, 1997, p. 28, tradução livre). Afinal, a fotografia humanista e a geografia humanista se aproximam ao se interessarem pelas ações dos sujeitos e as suas escolhas na sociedade, em seu espaço-tempo, considerando os sistemas de valores, as preferências, as crenças, etc. A geograficidade e, nesse contexto, a fotograficidade, portanto, podem ser entendidas como os modos de existência e destino dos seres humanos. 
Figura 1 - Foto A: Os irmãos, rua do Doutor Lecène, Paris, 1934. Foto B: O Carpinteiro na rua Saint Louis em Isle, 1947.
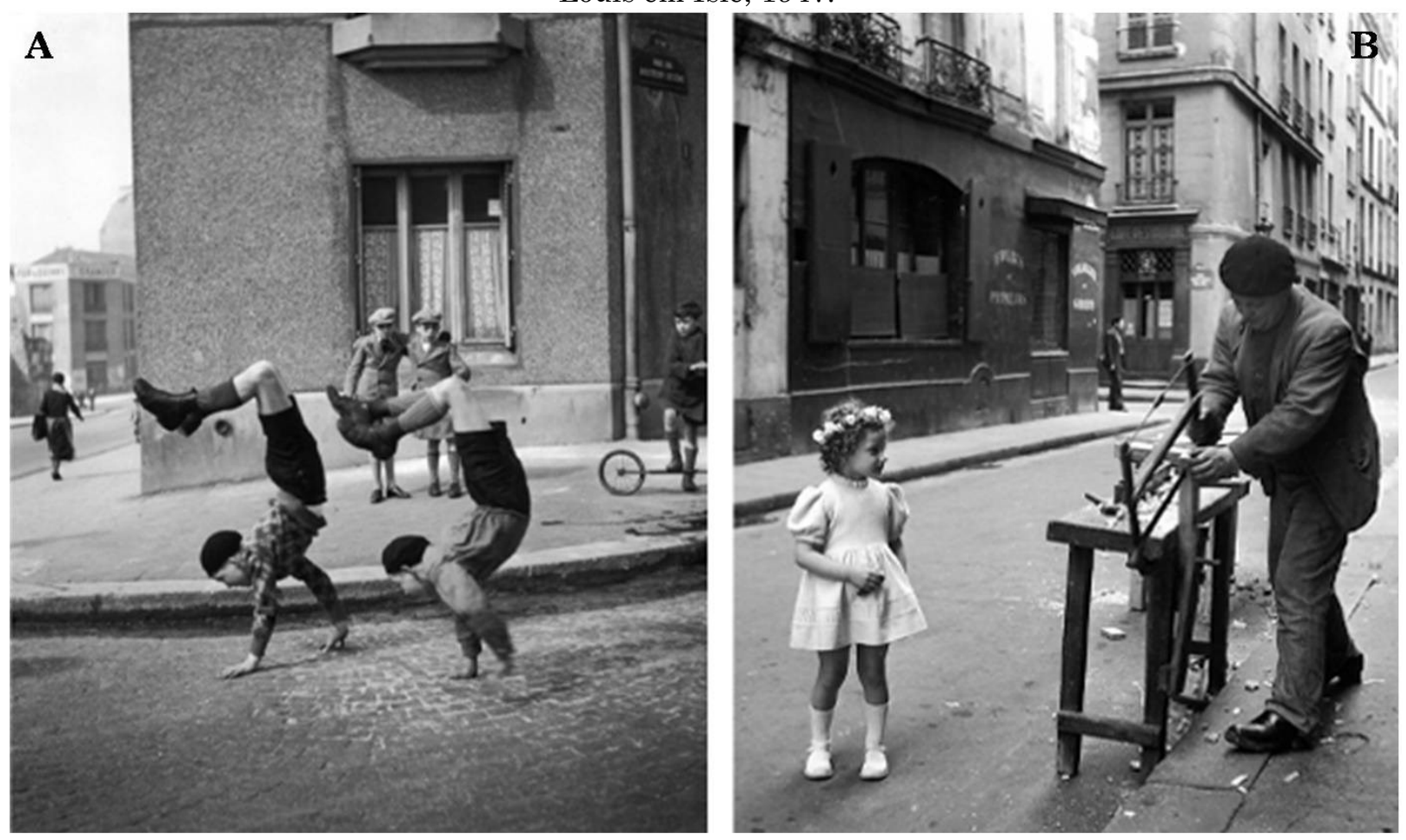

Fonte: Doisneau (2014-2020).

O conjunto ambiente-sujeito, essa relação inextricável, era primordial para a fotografia humanista assim como o é para a geograficidade. Os fotógrafos humanistas destacavam tanto o modo de vida íntimo quanto a vida pública das ações dos seres humanos construindo e vivendo seus espaços; tanto é que se utilizavam muito da perspectiva de profundidade de campo para capturar o ambiente e o motivo humano a ser fotografado, pois ambos faziam parte de um todo. Como indica Pidner (2017, p. 310, grifo do autor), ao discutir a geograficidade na paisagemfotografia, "O visível do detalhe revela o sujeito fotografado, que também é paisagem, mas igualmente remete ao invisivel contexto espacial no qual aqueles sujeitos-corpos se inserem e com o qual experimentam suas práticas espaciais". Paviot (2019) ainda destaca alguns valores afetivos capturados a partir do olhar humanista do fotógrafo: ternura, otimismo, poesia, nostalgia, ingenuidade, humor, generosidade, a beleza escondida na realidade e a permanência por trás da mudança.

A fotografia humanista ocorreu no mesmo período do apogeu da fotografia documento, essa última diretamente ligada à imprensa informativa. Ao discorrer sobre estes dois momentos técnicos, ou melhor, sobre duas culturas em relação às suas mediasferas, quais sejam a grafosfera e a videosfera, Debray (1993) elenca uma série de qualidades da fotografia humanista frente ao que ele denomina de fotografia humanitária, como segue no Quadro 1.

As distinções apresentadas por Debray (1993) são reforçadas pelo fato de que a fotografia humanista fixou o seu olhar na esperança de um mundo melhor. Mesmo em uma época inserida em muitas dificuldades sociais, mantinha-se a figura humana em sua dignidade. Esse humano não era abandonado como um corpo sem história e separado do mundo. Capturava-se o humano inscrito em uma família, uma classe social, um lugar, um evento e, portanto, ele tinha uma identidade (Figura 2). Os fotógrafos humanistas foram considerados correspondentes da paz, conservaram grande respeito e empatia por seus semelhantes recusando $o$ voyeurismo e $o$ sensacionalismo, e tiveram uma visão otimista do ser humano (MAILLET; DENOYELLE; VERSAVEL, 2006). 
Quadro 1 - Algumas linhas de fraturas entre dois momentos culturais da fotografia.

FOTOGRAFIA HUMANISTA

Autêntica, honrosa.

Originária da Grafosfera.

Atua com rico elenco: trabalho, amor, jogo, amizade, festas, infância, espetáculo.

Pertence ao universo das obras.

Furo poético ou foto de gênero.

Tem uma assinatura.

Edição tipográfica, voltada a livro, álbum, jornal.

No cinema e do realismo poético há solidariedade às artes cênicas (de palco ou de rua).

O visual opera sob comando verbal e está incorporado na foto.

O indivíduo não está isolado, porém inserido em seu lugar no grupo, família, cidade.

Rosto humanístico como o de uma paisagem urbana, com amplo campo de fundo.
FOTOGRAFIA HUMANITÁRIA

Comovente, destacando doença, fome, valores.

Originária da Videosfera.

Tem um sujeito imposto, a exemplo da beleza por intermédio da foto de moda. Pertence ao universo dos documentos. Furo Jornalístico ou fotorreportagem. Tem crédito por meio de uma agência. Televisual, sem profundidade de campo, coletiva ou individual.

Direta, literal e um tanto seca.

Verbal comandado pelo visual com legenda sob a foto.

O homem está livre de si próprio. O indivíduo é um corpo sem história.

Urgência lhe dá sentido, frente ao desolo e a falta de valores próprios.

Fonte: Elaboração dos autores a partir de Debray (1993).

Figura 2 - Foto A: O barão William e seu lacaio, Paris, 1955. Foto B: Os gatos dos mendigos, Paris, 1950.
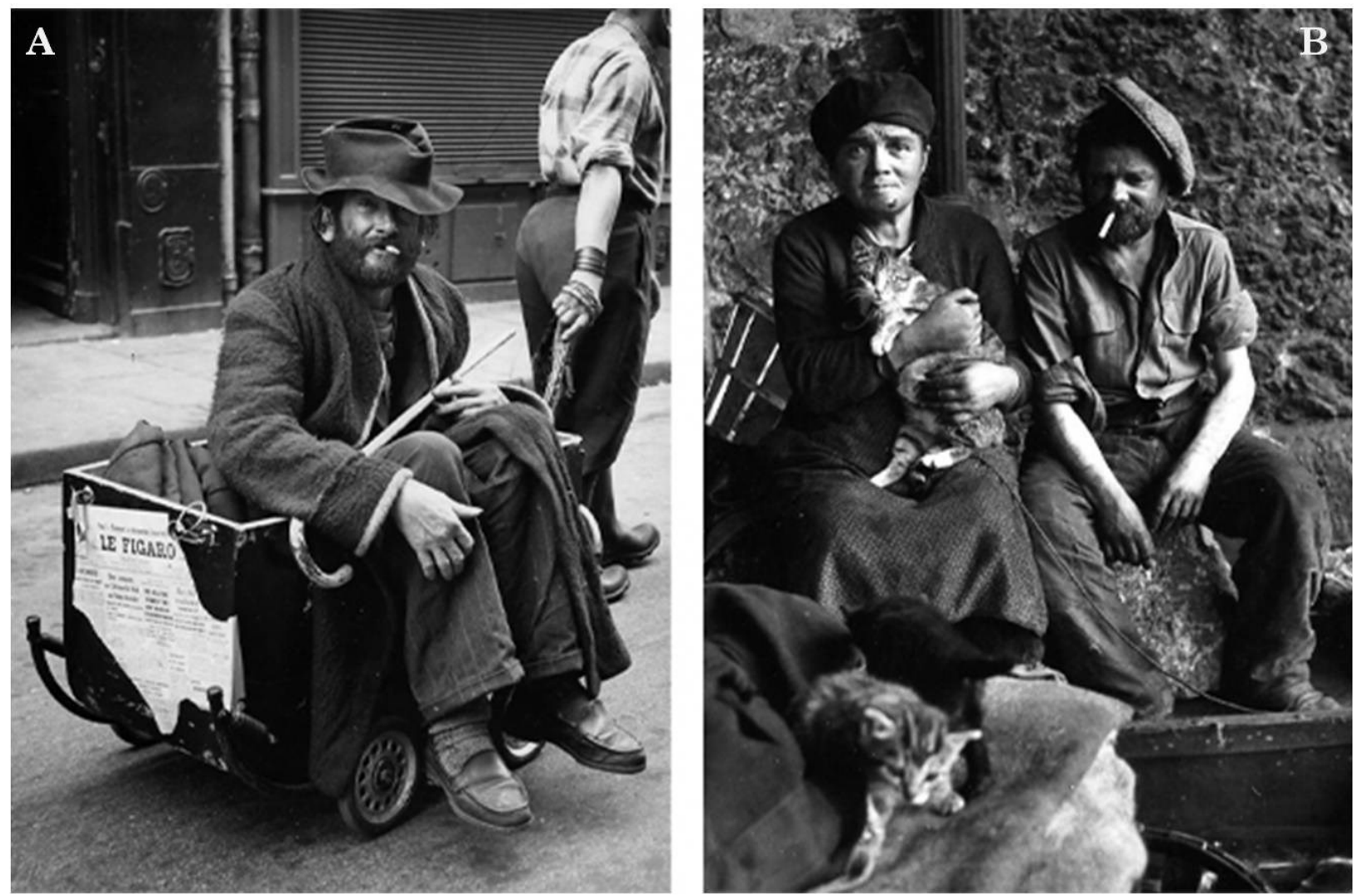

Fonte: Doisneau (2014-2020).

Se os fotógrafos humanistas tiveram a intenção de revelar a poética escondida no coração da realidade mais banal, demonstrando as maravilhas da vida cotidiana (MAILLET; DENOYELLE; VERSAVEL, 2006), torna-se essencial neste ensaio capturar um sentido duplo, imagético e poético, dos festejos como 
forma sensível de vivenciar o Círio de Nazaré. Justamente porque o "realismo poético", como é denominada a fotografia humanista, é considerado uma mistura entre o realismo social e a poesia do cotidiano. Nesse sentido, geograficidade e poesia amalgamam-se à fotografia humanista para dar "corpo e alma" à fotograficidade, maneira de captarmos a partir da fotografia, aquilo que Dardel (2011, p. 30) expressa ao tratar da paisagem: “[...] um conjunto, uma convergência, um momento vivido, uma ligação interna, uma 'impressão', que une todos os elementos".

Seguimos, então, ao encontro do "furo poético" do qual fala Debray, utilizando-se das lentes do fotogeógrafo.

\section{A geograficidade e a conversão semiótica do imaginário poético em fotopoemas}

Uma cidade ativa não é um espaço inerte, mas um espaço que se move, um espaço vivo (DARDEL, 2011, p. 14).

A cidade ativa quer dizer que ela é humana em formas e graus diferentes. A cidade é idealizada por pessoas de acordo com suas intenções e motivações. Esta é uma questão crucial para entender-se a fotograficidade do Círio de Nazaré, em Belém do Pará. É durante o Círio que Belém pulsa em poesia e imagens vivas e ativas.
Nomeamos esse reencontro do olhar fotográfico com a criação poética por fotopoemas. Tal criação remete a antigas imagens de "santinhos", popularizadas em folhetos de orações com a figura de um santo protetor. Mas também remete a imagens atualizadas, multiplicadas telas digitais, como uma espécie de infosfera (seguindo a perspectiva de Debray), na expansão das redes sociais. Cada fotopoema requer uma representação de fotograficidade capaz de registrar esse instantâneo da imagem no alargamento da reverência ali imaginada. $\mathrm{O}$ olhar fotográfico é dinamizador de geografias devocionais em formas poéticas, mesmo quanto a leitura é breve.

Um pulsar freneticamente humano, quebrando radicalmente a repetição dos dias comuns, em construção sinuosa e bricolagem performática. O que se compreende é o exercício duplo, de compressão e expansão, da fé coletiva e da festa, agora universal, sob o signo da patrimonialidade imaterial da humanidade conforme a declaração de salvaguarda da UNESCO em 2013. O que faz da pulsação humana uma projeção multiescalar (tão local quanto global) das representações da festa em liturgia das imagens. Observamos esse retorno performático da Santa e seu cortejo à Basílica (Figura 3).

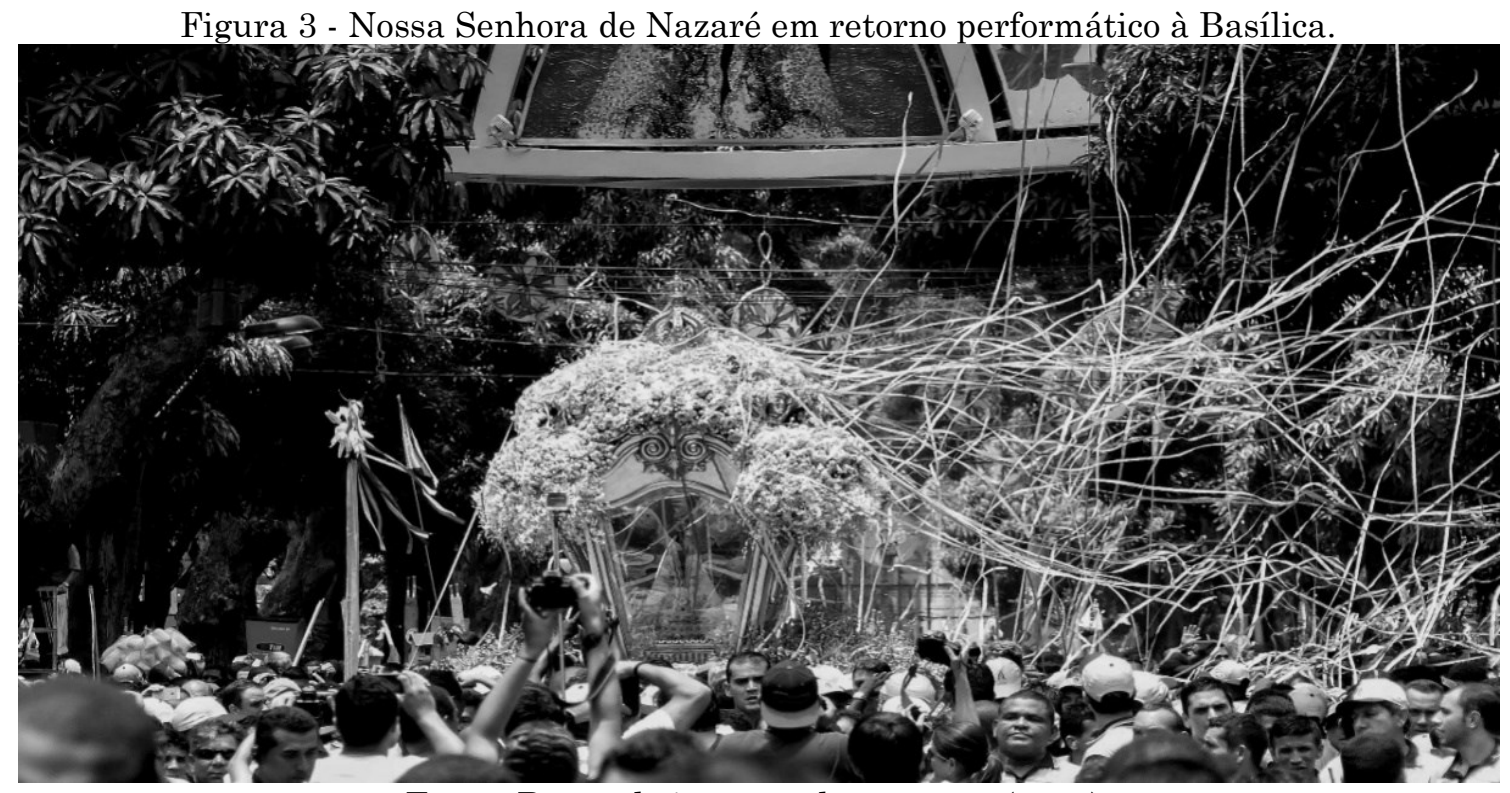

Fonte: Banco de imagem dos autores (2014).

O que temos no alinhamento da multidão, berlinda em serpentinas e árvores no plano mais elevado? Um jogo de espaço e tempo indistintos, onde palcos são montados e imagens performáticas são neles cenas e cenários reproduzidos como festa. Espaço-tempo impulsionado e jogado a esferas mais sutis durante os festejos. O círio, em sua simplicidade e expressão litúrgica da vela pascal, no tempo comum eclesial e no espaço místico de uma 
histórica capital amazônica, encontra em Nazaré um Grande Círio Ritual.

No Círio, o mundo comum ordinário, ou mundo empírico das percepções sensíveis e o mundo imaginal (CORBIN, 1976), ou o mundo intermediário, de interseção, onde estão as figuras arquetípicas, os corpos sutis, se fundem. O alcance do imaginal não é pura ficção. Apesar de diretamente inacessível, é real no sentido de que é mantido pelas tradições em suas "utopias visionárias ou espirituais" (WUNENBURGER, 1979; 1985; 2002a; 2002b; 2003). O Círio é uma variação desses dois temas ou mundos utópicos interconectados, pois são motivos simbólicos alimentando-se da imaginação mítico-profética ou imagens religiosas do outro mundo.

$\mathrm{Na}$ fronteira do mundo material, onde se insere a atividade humana, e do mundo imaginário, abrindo seu simbolismo à liberdade de espírito, nós encontramos aqui a geografia interior, primitiva, onde a espacialidade original e a mobilidade profunda do homem desenham direções, traçam caminhos para um outro mundo (DARDEL, 2011, p. 8).
Eis um importante teor fenomenológico da geograficidade de Dardel (2011): revelar os signos aparentes e ocultos da Terra, suas essências, afinal, para ele, o mundo é uma escritura a ser decifrada, procurando dar conta da continuidade ou releitura entre as coisas e da fusão do homem e da terra (RAFFESTIN, 1987; LÉVY, 1992). A geograficidade é uma atitude complementar entre ciência, observação pessoal e poética (HOLZER, 2016), elementos que precisam andar de mãos dadas. Por isso, tanto o mundo concreto relacionado ao Círio quanto o mundo imaginal o qual lhe cede o combustível necessário, não estão distantes um do outro; entre eles há uma fronteira tênue e transponível alimentada pelas utopias visionárias ou espirituais (Figura 4).

Figura 4 - Cenas performáticas alimentadas pelas utopias espirituais.
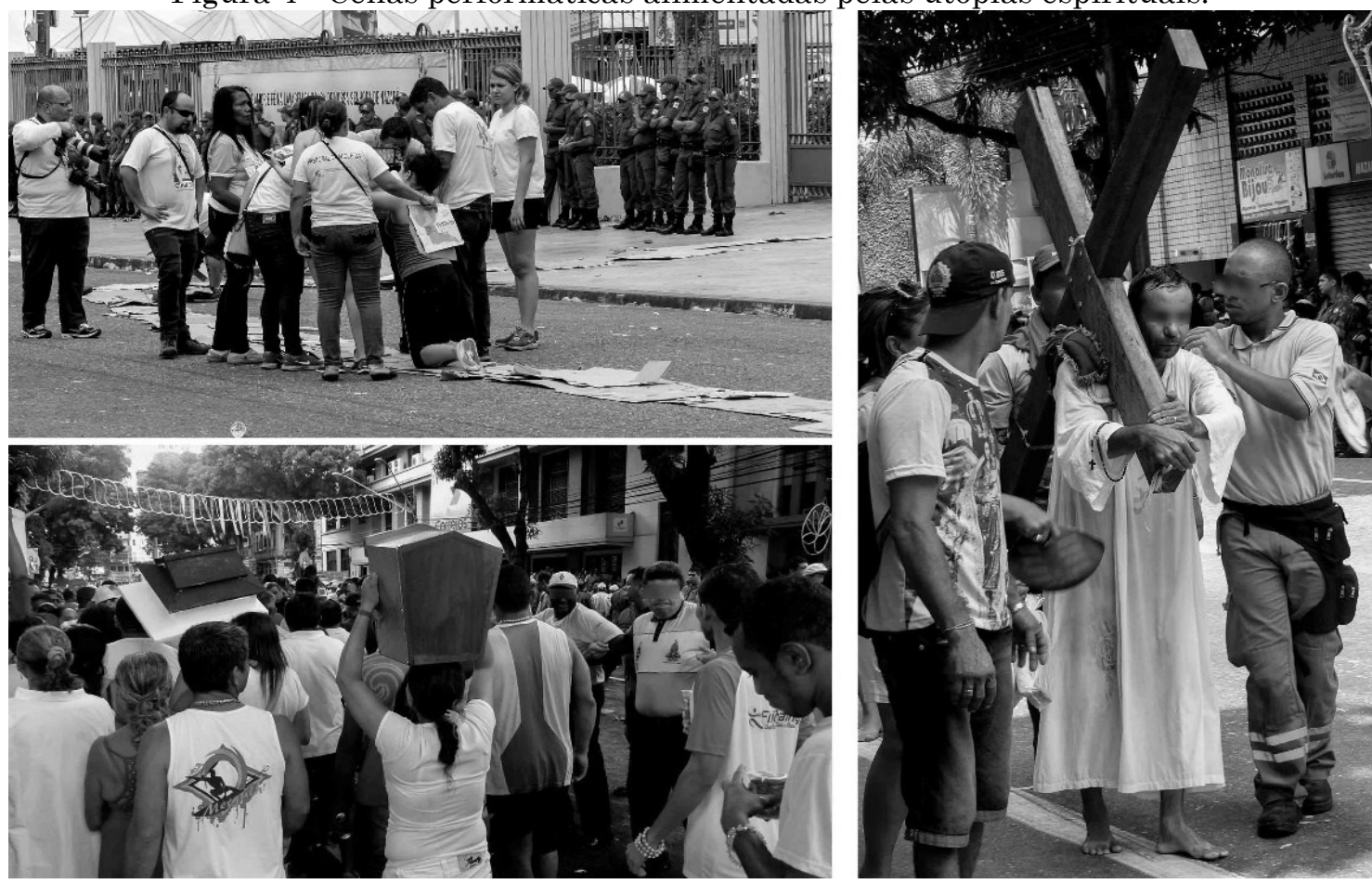

Fonte: Banco de imagens dos autores. Foto: autores (2014).

Raffestin (1987) percebe isso no pensamento de Dardel ao observar que não há uma ruptura ou descontinuidade entre o mito e o logos, entre o religioso e a lógica, porque Dardel, diz ele, persegue uma totalidade. Mais ainda, o espaço mítico não quer dizer uma confusão de lugares, pois está condicionado por uma hierarquia de valores a partir de um centro. Sendo a geograficidade também uma atitude poética, sua expressão literária dá o suporte necessário à fotograficidade. $\mathrm{O}$ que se renova pela proposição dos fotopoemas, que apresentamos adiante. 
Em fotopoemas, a fotograficidade do Círio de João Loureiro

No livro Cultura amazônica: uma poética do imaginário (2015), João de Jesus Paes Loureiro aborda o que denomina de "imaginário poético estetizante" presente no sistema cultural amazônico.

João de Jesus Paes Loureiro. Poeta, prosador e ensaísta. Professor de Estética e Arte. Sua obra poética tem sua universalidade construída a partir de signos do mundo amazônico cultura, história, imaginário - propiciando uma cosmovisão e particular leitura do mundo contemporâneo. Dialogando com as principais fontes e correntes literárias da atualidade, Paes Loureiro realiza uma obra original, quase uma suma poética de compreensão sensível do mundo por meio das fontes amazônicas, em que o mito se revela como metáfora do real.

Criativamente, diz ele, o homem da Amazônia navega numa espécie de sfumato, uma névoa que funde o real e o irreal desembocando numa realidade única. Nessa fusão, o poético vibra e envolve toda a atmosfera cultural amazônica. Loureiro (2015) propõe, então, o conceito de conversão semiótica no sentido de um movimento de passagem "[...] pela qual as funções se reordenam e se exprimem em uma outra situação cultural. A conversão semiótica significa o quiasmo de mudanças de qualidade simbólica em uma relação cultural no momento em que ocorre uma transfiguração" (LOUREIRO, 2015, p. 61).

$\mathrm{E}$ nada mais interessante para apresentar essa conversão semiótica do imaginário estetizante do que seus poemas. Neles, o humano e o ambiente, vivos, estão em movimento, são captados pela máquina natural ocular do poeta e levados ao cérebro quando são processados e transformados em abstração intelectual. $\mathrm{O}$ poder imaginativo das poesias ilustra o imaginário estetizante do/no Círio. O poeta persegue a dimensão simbólica de uma cultura específica. Traz à tona e desencobre a névoa que perpassa as camadas de realidades construídas nos percursos encenados dos festejos. Sua linguagem simbólica é um trajeto entre o real e o incognoscível que também se faz real.

O intercâmbio entre poesia e fotograficidade - como um fotopoema- oferece-se em complemento e o sfumato proporciona a textura do Círio. Os espaços performáticos tornam-se plenos da potencialidade festiva da fé em ritos e registros da imaginação. $O$ humano e $\quad 0$ humanismo são metaforizados. O Círio de Loureiro é fenomenologicamente, ao mesmo tempo, existencial e natural. Ser humano e natureza se amalgamam produzindo os espaços e os territórios por onde ele é encenado.

Apesar de não ser geógrafo, embora possamos tratá-lo como tal a partir de sua geografia pessoal ou vernacular (MONNET, 1999; COLLIGNON, 2005; CLAVAL, 2010), os poemas de Loureiro têm caráter geopoético, por lançar luz sobre o "diferencial de novidade" espacial por intermédio de uma geografia poética e existencial. De acordo com Lévy (1992,p. 29, tradução livre), "O que poderia ser mais normal para uma arte de expressão, a poesia, que deveria criar novas imagens, inflamar nossa imaginação e renovar nossa percepção, como que a deixar uma marca inédita?" Dá-se então continuidade à procura do "furo geopoético", compondo a poesia do texto da poesia visual.

Passemos então à releitura da obra de João Loureiro, na sequência de sete composições em fotopoemas (Figuras 05 a 11), cientes de que a técnica projetiva de busca qualitativa desse regime fotográfico humanista tem muito a se expandir em outras frentes de catalogação e análise contemporânea da ciência geográfica.

A Figura 5 associa o poema "O Círio" a um foco de caminhantes, denso e caudaloso, como peixes na "correnteza de um rio com alma e devoção", um "cardume de canções" levados por "ondas submarinas". Um rio devoto, incapaz de ser compreendido apenas pela representação dos milhões de visitantes na procissão. É sabido que outros Círios, no interior do Pará, antes e depois do outubro de Belém, atestam essa captura do corpo coletivo "navegado pela fé". Contudo, a correnteza do registro local sintetiza essa primeira escala humanista. Não há festa do Círio de Nazaré sem conexão coletiva. A individuação é uma aparente exclusividade da Santa na berlinda; muito embora, isso só permaneça ao olhar desatento de quem vê/sente conjuntos sem observar os detalhamentos.

E na Figura 6 é perceptível o destaque, a figura angelical do carro/barco, centro dessa travessia coletiva na representação das crianças em sua pureza e idealidade divinal. Muitas vezes se elegem os pequeninos seres para, posicionados nesses altares móveis, ocultar e revelar a multidão de anjos - nas palavras do poeta, "nuvem de anjos passando..." - como se esses pequenos seres celestiais fossem uma representação perfeita de nossos olhares e desejos. Nas "asas de anjos pousando", a Santa nos indica um acesso devocional alternativo. Como brincadeira e passeio, antes do próximo cortejo. 
Figura 5 - O Círio é uma multidão de ondas caminhantes. Um rio de devotos.

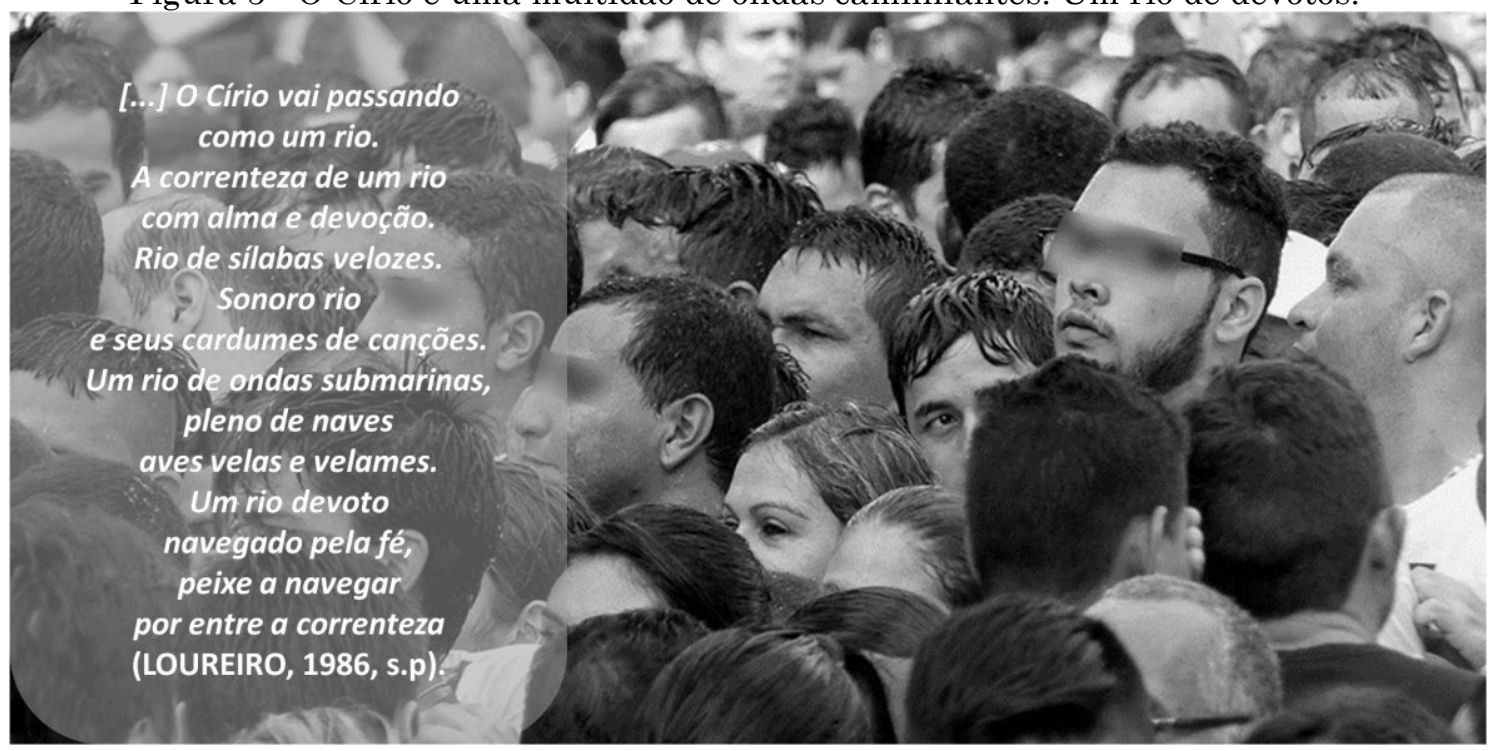

Fonte: Banco de imagens dos autores (2014).

Figura 6 - O pequeno anjo deixa seu carro e, suavemente, passeia absorto a brincar.

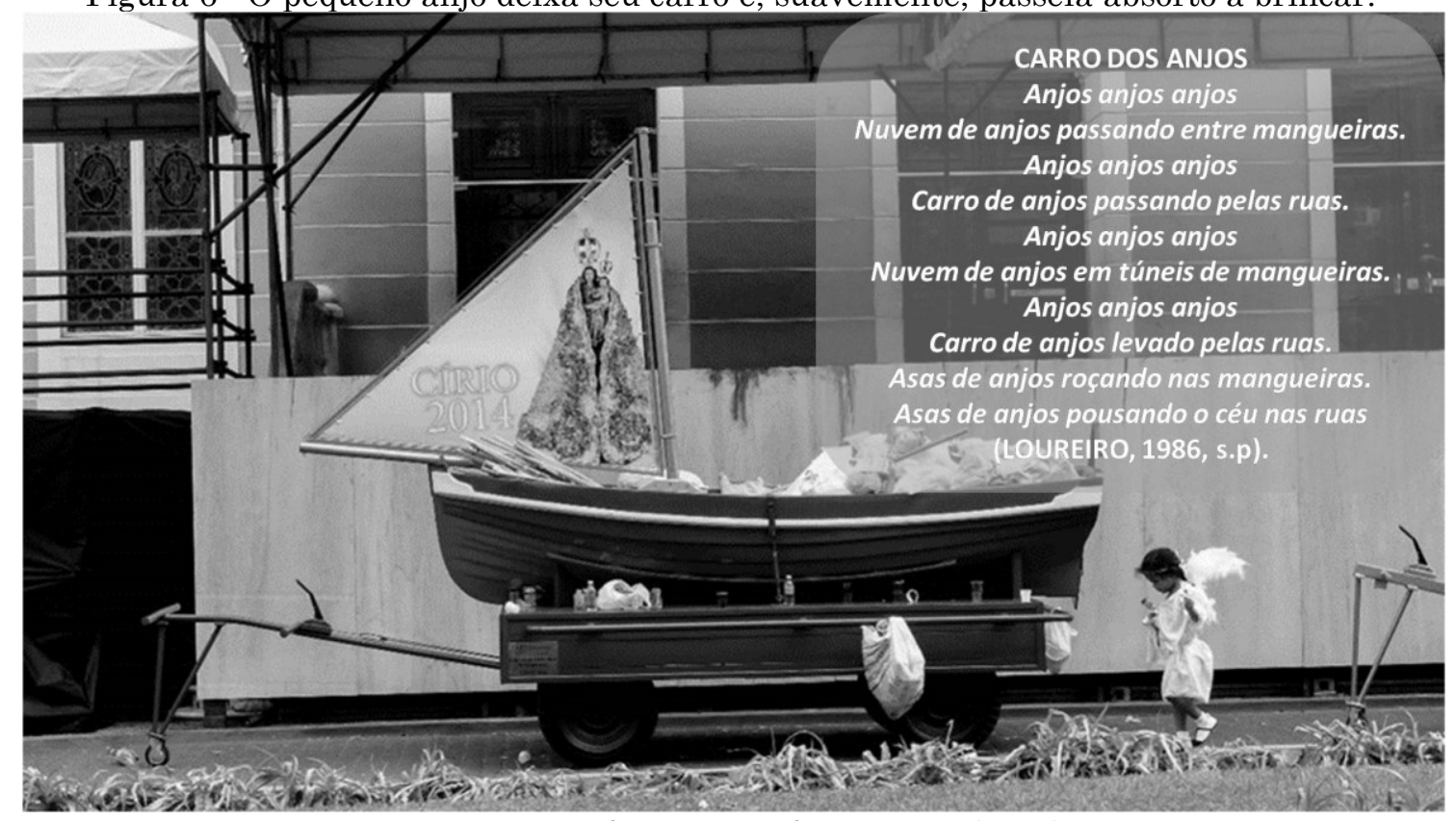

Fonte: Banco de imagens dos autores (2014).

E o cortejo tem seu início como um jardim em suspensão. O fotopoema a seguir (Figura 7) retrata este momento de ingresso da Imagem Santa na berlinda. A "Senhora de Nazaré" é observada pelo carinho e apreensão dos devotos neste traslado de alto risco. Transição do fixo para o fluxo, "barca de flores" aguardando "Iara boiando em águas encantadas", em uma passagem como vinda "coroada de sonhos". Expressão que denota também o equilíbrio entre o sentimento de protegê-la e ode sentir-se protegido por ela. Por isso, a única proteção de fato é a certeza de sua mensagem infinita: só não hás de passar no meu coração. Partida e chegada se mesclam em um único ritual.

As avenidas decoradas por mangueiras formam o cenário especial do cortejo, como uma forma de representar a frutificação daquela folia santa. A Figura 8 demarca a chegada do carro dos milagres com suas levas de guardiões na linha de frente e sua diversidade de desejos lançados, como promessas por novos tempos: "cabeças destroncadas, destroços de poesias, cacos de esperança". Tudo que a nave carrega representa simultaneamente os sonhos mais íntimos da vontade de vida individual e da superação coletiva frente às injustiças da vida. 
Figura 7 - Aqueles que te levam pelas ruas no azul levíssimo da alma.

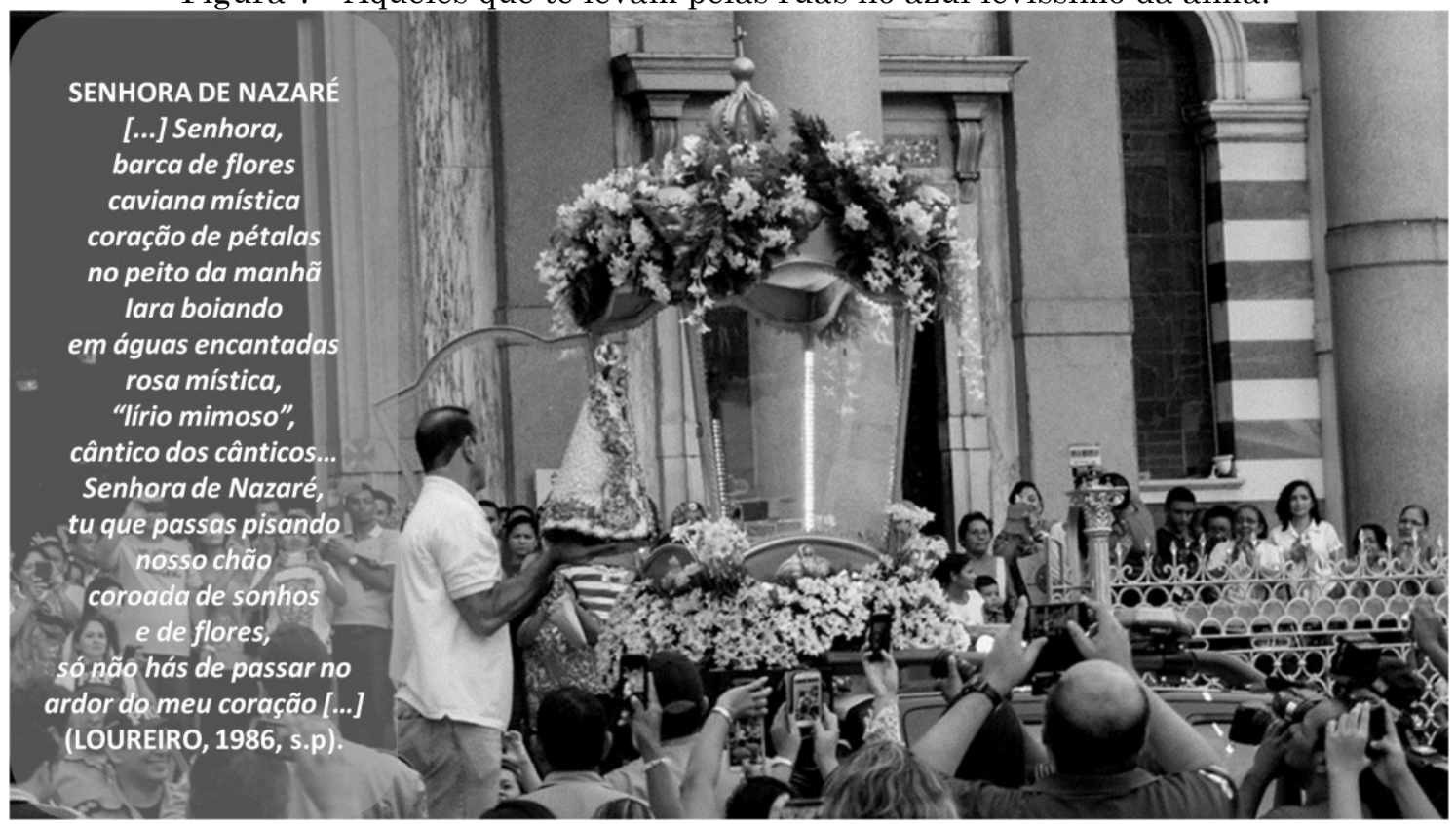

Fonte: Banco de imagens dos autores (2014).

Figura 8 - O carro dos milagres é tripulado por sonhos entre mangueirais.

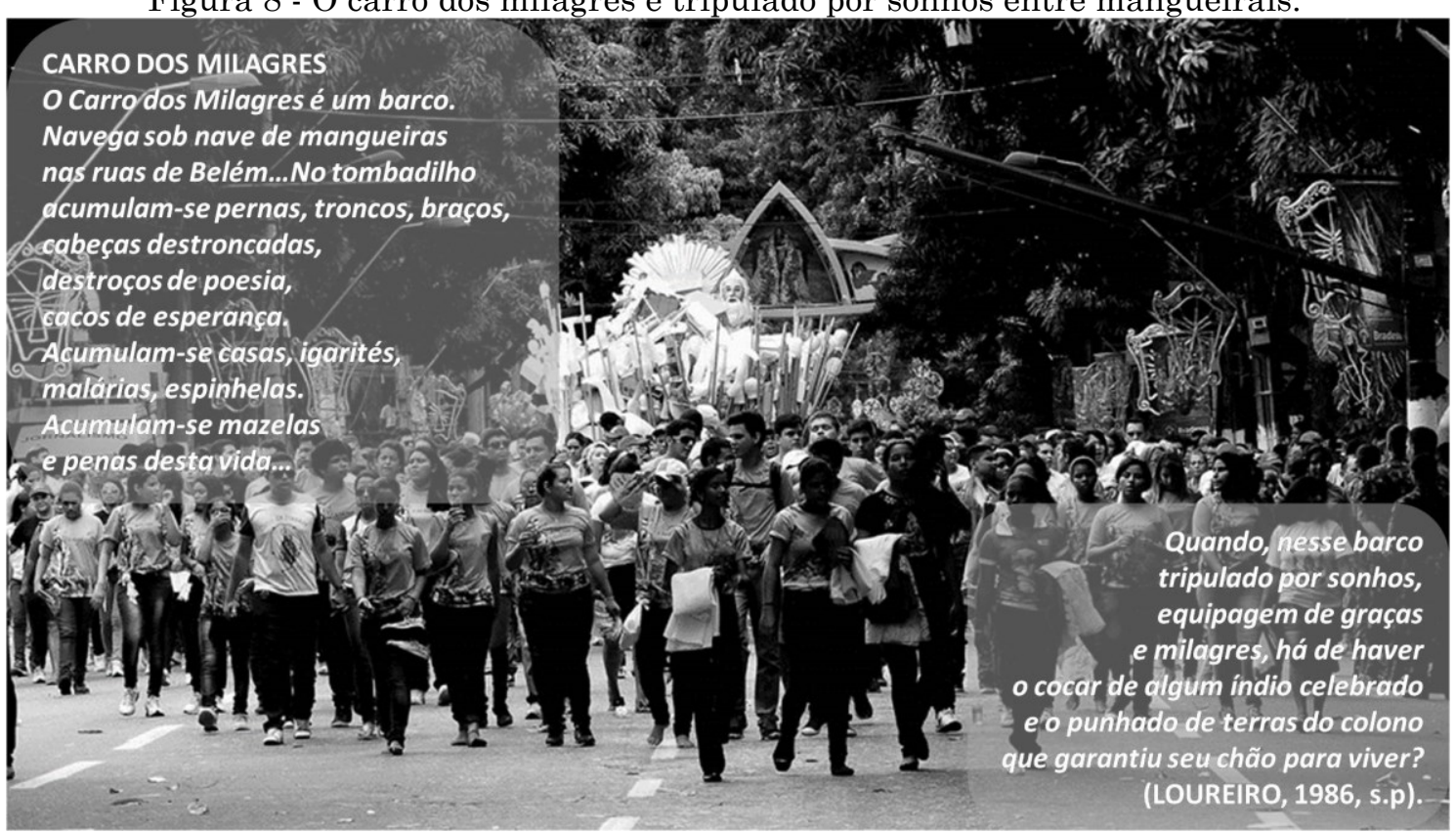

Fonte: Banco de imagens dos autores (2014).

Nessa nave "há de haver, o cocar de um índio celebrado e um punhado de terras do colono que garantiu seu chão para viver?". A dúvida é certificada pela identificação dos devotos com a força cabocla dos jovens que se adiantam, guiando e antecipando a nave santa.

A Figura 9 é a projeção externa no interior da cidade. Habitação de madeira e vidro, florida como a copa primaveril da floresta barroca de
Belém que abriga inúmeros quereres. Diz o poeta, entre tantas vontades... "quisera ser esse raio de sol... quisera ser um hino a rebrotar... quisera ser os passos da paixão". Todavia, para que o alcance do querer se dê, apenas a Graça, a graça medianeira da Santa, como "o tema da canção que passa por entre a melodia”. Não há relação direta, causal, mecânica na devoção. 
Figura 9 - A virgem na berlinda meio à multidão.

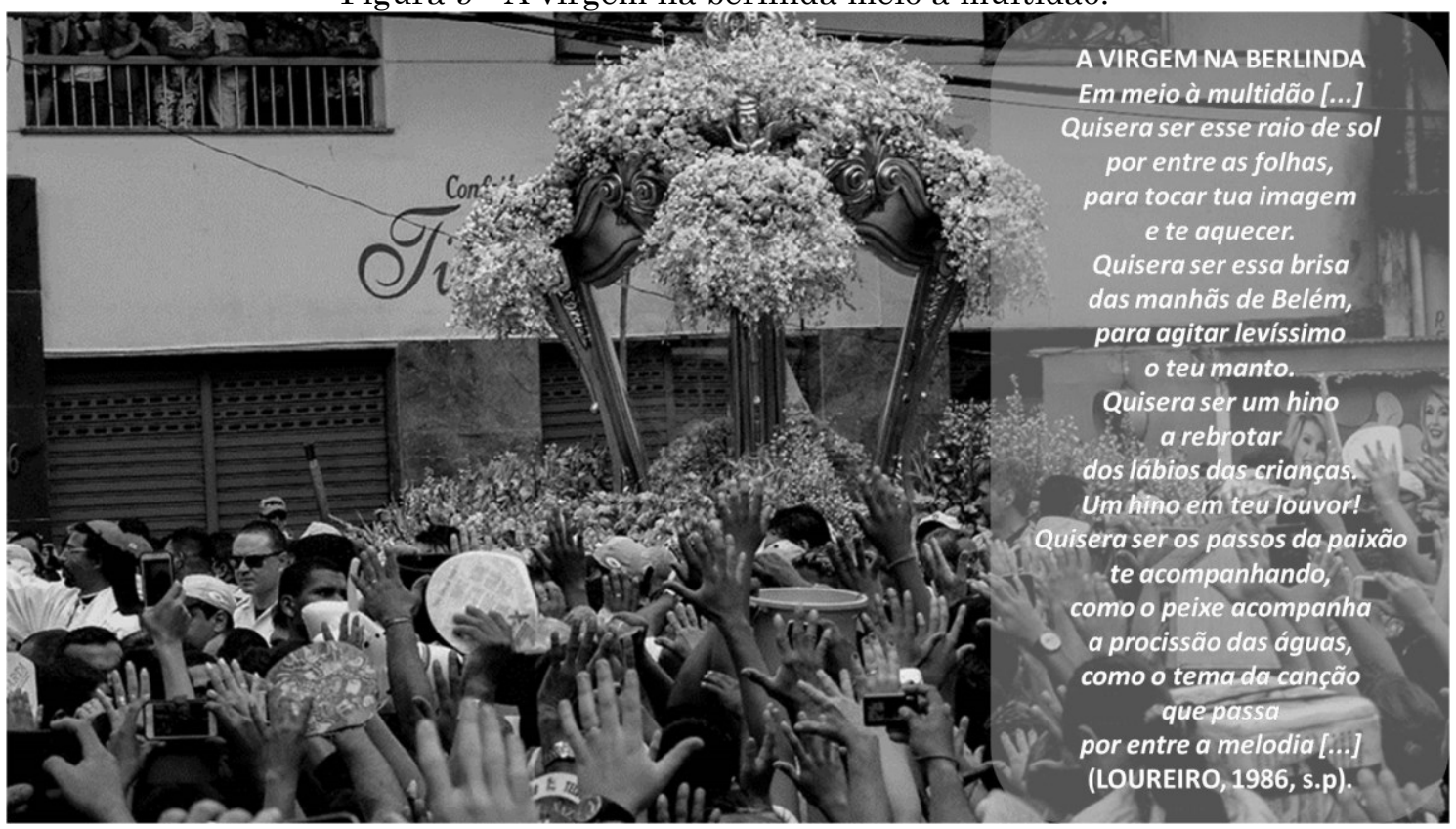

Fonte: Banco de imagens dos autores (2014).

E quando se nega tal relação causal direta reafirma-se a possibilidade maior de intervenção divina, entrelaçada ao conjunto de laços identitários. As Figuras 10 e 11 demonstram, na imagem da Corda/Andor (de barras) e na concentração de devotos para Moto- romaria, um jogo de técnicas que enfatizam o aspecto colaborativo. Logo os fotopoemas podem também deslocar o centro humanista da observação: do sagrado tradicional para o profano diretamente referendado nas dimensões de novas sacralidades.

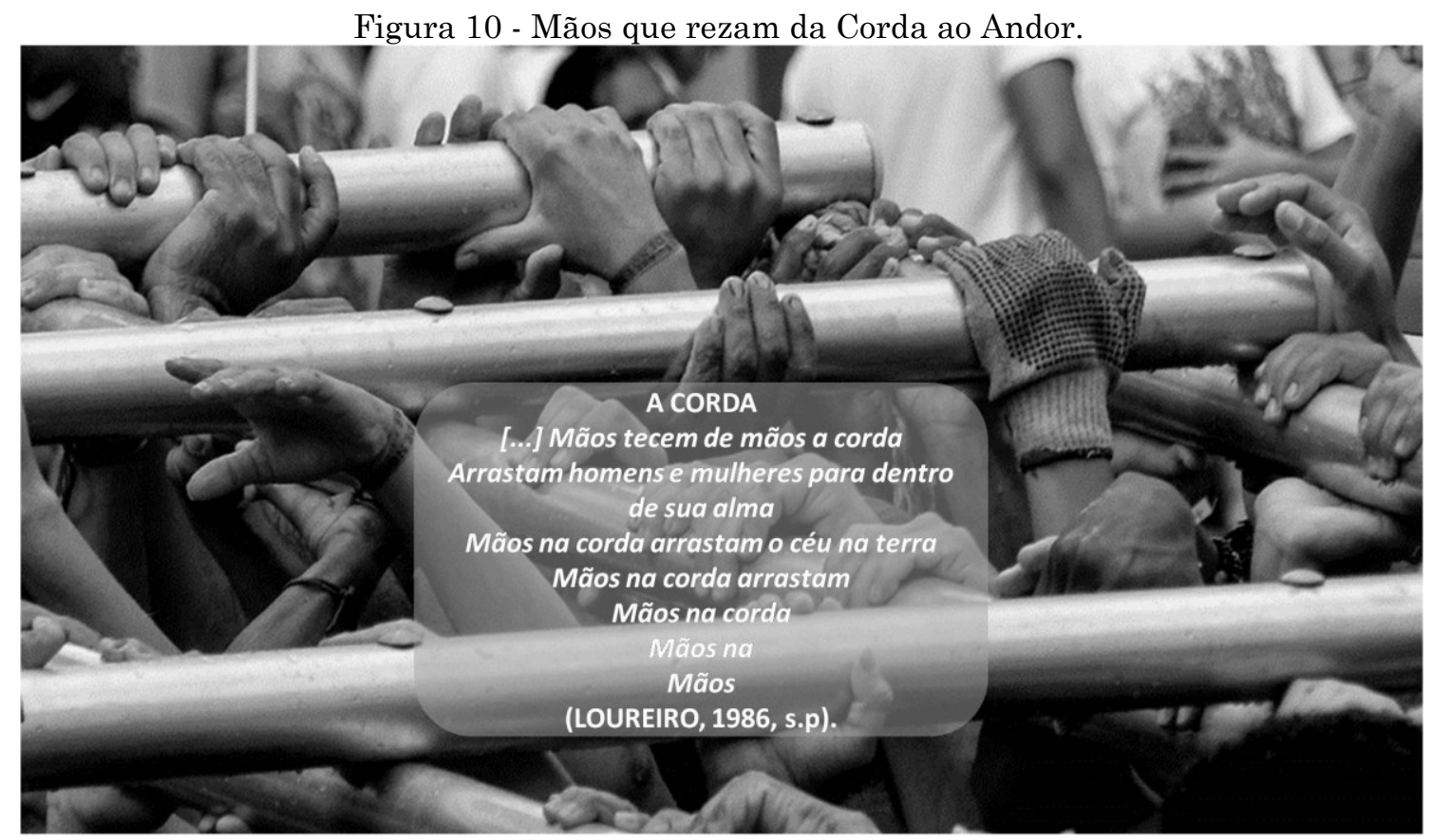

Fonte: Banco de imagens dos autores (2014). 


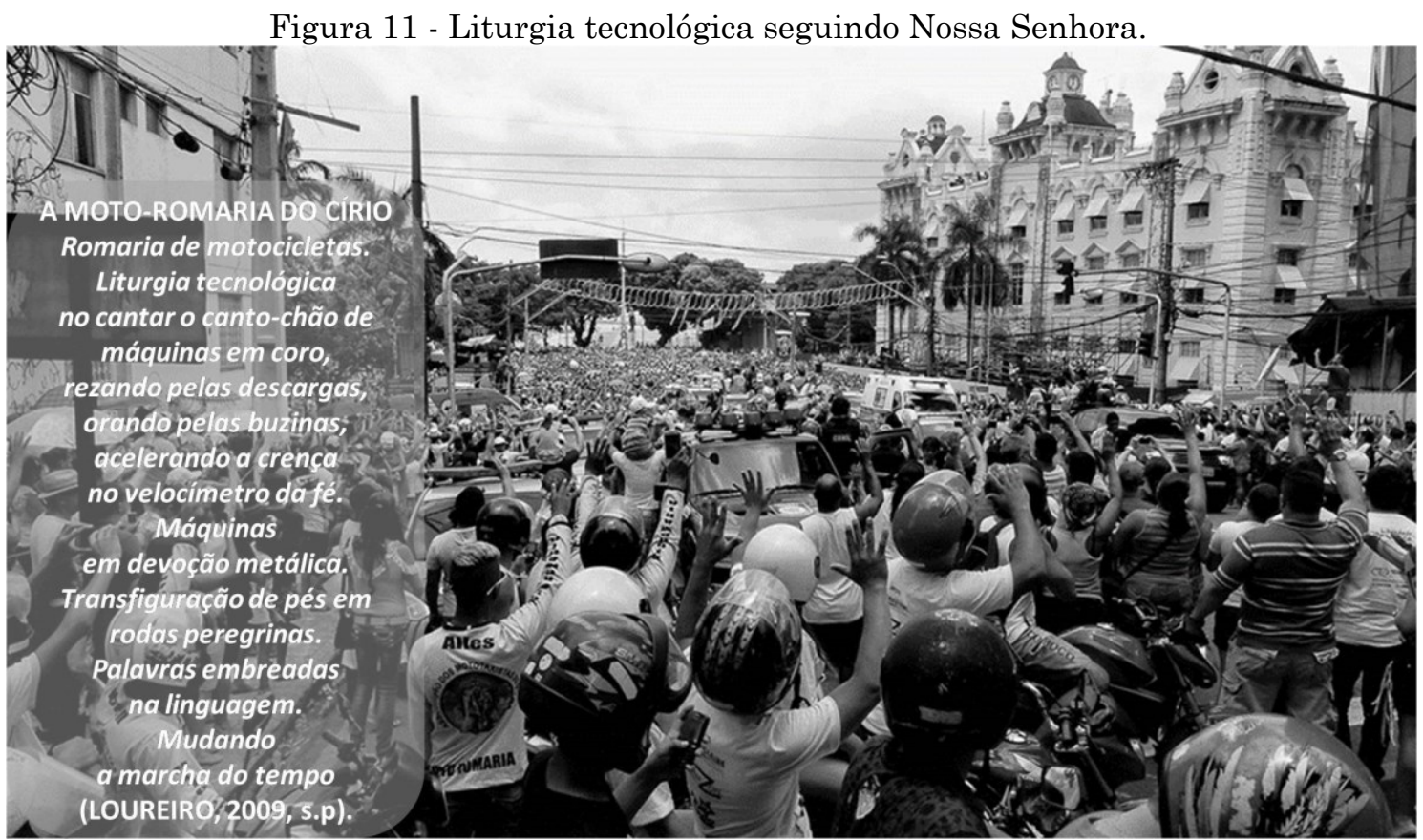

Fonte: Banco de imagens dos autores (2014).

\section{CONSIDERAÇÕES FINAIS}

Voltemos a Dardel (2011) para desvelarmos essa poética, tanto imagética quanto literária, que acabamos de apresentar. Para o referido geógrafo, a ciência, em seu rigor, não perde em nada quando confia a sua mensagem, a sua narrativa, a um observador que sabe admirar e selecionar a imagem justa e luminosa. Poderia esse observador ser o fotógrafo? Mais que isso, poderia ser ele um fotogeógrafo interessado na potência da imagem em mostrar a diversidade de relações existentes entre as pessoas e o mundo?

Para Costa (2014), as fotografias e as imagens, de forma geral, não congelam um dado espaço-tempo. Ao contrário possibilitam reconhecermos o movimento ao mesmo tempo individual e coletivo da história e da geografia do mundo. Maneira de situarmos as imagens do passado, do presente e do futuro na profusão cada vez mais cibernética em que são criadas, para não esvaziarmos os seus conteúdos e sua potência interpretativa.

Até porque, conforme Bertrand (2014), ao associarmos Geografia e Fotografia, uma ciência e uma técnica, e ainda aliados à poesia que nos reapresenta o mundo ao recriá-lo, nos esforçamos em apreender nas profundezas da paisagem as coisas que estão por de trás da paisagem.

As fotografias junto das poesias, transmutadas em fotopoemas, portanto, ganham em cor, densidade, espessura e profundidade. Afinal, tratamos aqui de linguagens, maneiras de comunicar eventos e eventualidades. Linguagens que, ao se tornarem mais diretas, ao se aproximarem da arte, falam "sem dificuldade à imaginação" (DARDEL, 2011, p. 3).

Fotograficidade, nesse contexto, é a geografia em ato, geografia aberta ao dito (o sentimentopalavra), daquele que com uma câmera fotográfica na mão busca revelar a condição humana no contexto de sua abertura e intencionalidade poética. Fotograficidade de fotopoéticas em fotopoemas. Tudo presente no instante, no aqui e no agora, expressando o passado e o futuro a partir do presente, que lembra, anseia e realiza. Porque o presente é o único momento em que o homem vivência a realidade (BACHELARD, 2007). Geograficidade do mundo em um instante poético de enquadramento.

\section{REFERÊNCIAS}

ALVES, I. O carnaval devoto: um estudo sobre a festa de Nazaré, em Belém. Petrópolis, Vozes, 1980.

ALVES, I. A festiva devoção do Círio de Nossa Senhora de Nazaré. Estudos avançados. Vol. 19, número 54. São Paulo May / Aug. 2005. Disponível

em: https://www.revistas.usp.br/eav/article/view/1 0083/11655. Acesso em 7 de abril de 2021.

AVANCINI, A. A imagem fotográfica do cotidiano: significado e informação no jornalismo. Brazilian journalism research: 
journalism theory, research and criticism, Brasilia, v. 7, n. 1, p. 50-68, 2011. https://doi.org/10.25200/BJR.v7n1.2011.285

BACHELARD, G. A intuição do instante. Trad. Antonio de Pádua Danesi. Campinas, SP: Verus Editora, 2007.

BERTRAND, G. Prefácio: olhares cruzados, imagens enquadradas. In: STEINKE, V. A. et al (orgs.). Geografia e fotografia: apontamentos teóricos e metodológicos. Brasília: Laboratório de Geoiconografia e Multimídias - LAGIM, UnB, 2014, p. 6-9.

BRAGA, C. "Imagination", "imaginaire, "imaginal: three concepts for defining creative fantasy. In: JSRI, n.16, Spring 2007. p. 59-68. http://jsri.ro/ojs/index.php/jsri/article/view/425 /423. Acesso em 8 de abril de 2021.

BRAGA, C. De l'utopie à lacontre-utopieaux XVI-XIX siècles. 2008. 530f. Thèse (doctorat) de philosophie - etudedessystèmes.Université Jean Moulin Lyon 3.

CLAVAL, P. Terras dos homens: a geografia. São Paulo: Contexto, 2010.

COLLIGNON, B. Quesait-on des saviors géographiques vernaculaires? (What do we know about vernacular geographic knowledges). In: Bulletin de l'Association de géographes français, 82e année, 2005-3 (septembre). La géographie économique au début du XXIe siècle: agglomération et dispersion/Géographie vernaculaire. pp. 321 331. https://doi.org/10.3406/bagf.2005.2467.

CORBIN, H. Mundus Imaginalis or the Imaginary and the Imaginal. In: Ipswich: Golgonooza Press, 1976. Disponível em: http://www.bahaistudies.net/asma/mundus_i maginalis.pdf. Acesso em: 29 de abril de 2021. p. 1-13.

COSTA, E. B. Paisagem-memória e função social da fotografia. In: STEINKE, Valdir Adilson et al (orgs.). Geografia e fotografia: apontamentos teóricos e metodológicos. Brasília: Laboratório de Geoiconografia e Multimídias - LAGIM, UnB, 2014, p. 79-106.

DARDEL, E. O homem e a terra: natureza da realidade geográfica. São Paulo: Perspectiva, 2011.

DEBRAY. R. Photo humaniste, photo humanitaire. Disponível em: http://regisdebray.com/pages/pdf/photo_huma niste.pdf. Acesso em 7 de abril de 2021. Texte publié em juin 1993. p. 1-4.

DOISNEAU, R. Atelier Robert Doisneau, 20142020. Página Inicial. Disponível em: https://www.robert-doisneau.com/fr/. Acesso em: 07 de abr. de 2021.

GOMES, P. C. C.; RIBEIRO, L. P. A produção de imagens para a pesquisa em geografia. In:
Espaço e Cultura, UERJ, Rio de Janeiro, n. 33, p.27-42, jan./jun. de 2013.

HOLZER, Werther. A geografia humanista: sua trajetória 1950-1990. Londrina:Eduel, 2016.

LÉVY, B. L'empreinte et Le déchiffrement: géopoétique et géographie humaniste. In: Cahiers de géopoétique, 1992, vol. 1, p. 27-35. Disponível em: https://archiveouverte.unige.ch/unige:18037. Acesso em 8 de abril de 2021.

LÉVY, B. Géographie humaniste, géographieculturelle et littérature. Position épistémologique et méthodologique. In: Géographie et cultures, 1997, vol. 21, p. 27-44. Disponível em: https://archiveouverte.unige.ch/unige:18298. Acesso em 8 de abril de 2021.

LOUREIRO, J. J. P. Cultura amazônica: uma poética da imaginação. $5^{\text {a }}$ Edição. Manaus: Valer Editora, 2015.

LOUREIRO, J. J. P. Poemas sobre o Círio de Nazaré. Blog do Paes Loureiro. Disponível em: https://paesloureiro.wordpress.com/2012/10/14 /poemas-sobre-o-cirio-de-nazare/. Acessoem 29 de março de 2021.

MAILLET. L. M.; DENOYELLE. F.; VERSAVEL. D. La photographie humaniste, 1945-1968: autor d'Izis, Boubat, Brassaï, Doisneau, Ronis....France / Editions Bibilothèque National de France, vol. 1, 2006.

MONNET, J. Images de l'espace à Los Angeles: éléments de géographiecognitiveetvernaculaire.

In:Communication au Colloque de l'Institut Universitaire de France. "Espace(s)", Toulouse, 1999b. p. 1-28.

PAVIOT. F. La Photographie humaniste est-elle une photographie sociale? In: Narthex: Art Sacré, Patromoine et Création. Publiéle 28 février 2019. Disponível em:https://www.narthex.fr/blogs/la-

photographie-un-oeil-pour-voir-le-monde/laphotographie-humaniste-est-elle-une-

photographie-sociale. Acesso em 7 de abril de 2021.

PIDNER, F. S. Geograficidade na paisagemfotografia. Revista de Estudos Ibéricos: Iberografias, número 13, ano XIII p. 309-312, 2017. Disponível em: https://pt.scribd.com/document/367244804/Ibe rografias-n\% $\% 2 \%$ BA 13 . Acessoem 5 de maio de 2021.

RAFFESTIN, C. Pourquoi n'avons-nous pásluÉricDardel? In: Érudit Revues. Cahiers de géographie du Québec, volume 31, numéro 84, 1987, p. 333-523. Disponível em: https://www.erudit.org/fr/revues/cgq/1987- 
v31-n84-cgq2656/021898ar/. Acesso em 8 de abril de 2021.

REIS JUNIOR, D. F. Aspectos históricos da fotografia e realizações em Geografia. In: STEINKE, Valdir Adilson et al (orgs.). Geografia e fotografia: apontamentos teóricos e metodológicos. Brasília: Laboratório de Geoiconografia e Multimídias - LAGIM, UnB, 2014, p. 11-44.

RAFFESTIN, C. Théorie Du réel et géographicité. In: Espaces-Temps, 1989, no. 40-41, p. 26-31. Disponível em: http://archiveouverte.unige.ch/unige:4365. Acesso em: 12 maio de 2020

ROSENDAHL, Z. Hierópolis: o sagrado e o urbano. Rio de Janeiro: Eduerj, 1999

WUNENBURGER, J. L'u topie ou la crise de l'imaginaire. France: Encyclopédie universitaire, Jean-Pierre Delarge,1979.

WUNENBURGER, J. Déclin et renaissance de l'imagination symbolique. In:Sociologie et sociétés, vol. 17, $\mathrm{n}^{\circ} 2,1985$. p. 41-52. Disponívelem:

https://www.erudit.org/fr/revues/socsoc/1985-

v17-n2-socsoc102/001844ar.pdf. Acessoem: 20 mai. 2021.

WUNENBURGER, J. Regard et transparence: utopie et philosophie. In: Quaderni. n. 40, Hiver 1999. Utopie I: la fabrique de l'utopie. p. 145-158. Disponível em: http://www.persee.fr/web/revues/home/prescri pt/article/quad_09871381_1999_num_40_1_14 33. Acessoem: 16 mai. 2021.

WUNENBURGER, J. L'ambiguïté utopique: temple de dieu ou prison de verre? In: PAUL, Jean-.Marie. Le systeme et le reve.
France:L'Harmattan. Coll. Ouverture philosophique, 2002a. p 37-58. Article em ligne dans: Phantasma. Centre de Recherche sur l'Imaginaire. Universitatea Babes-Bolyai, Cluj, Roman. Disponível em: http://caieteleechinox.lett.ubbcluj.ro/?p=3091. Acessoem: 23 mai. 2021.

WUNENBURGER, J. "L'imaginaire reste ummilieupsychique encore mal connu". Um entretienavec Jean Jacques Wunenburger. In:CaieteleEchinox, vol. 2, (Teoria si practica imaginii. Imaginar ul cultural), Dacia, 2002b. Disponível em: https://www.ceeol.com/search/article-

detail?id=243930. Acesso em: 23 mai. 2021 .

WUNENBURGER, J. Uma utopia da razão: ensaio sobre a política moderna. Lisboa: Instituto Piaget, 2003.

WUNENBURGER, J. O imaginário. São Paulo: Edições Loyola, 2007.

\section{CONTRIBUIÇÃO DO AUTOR}

Raimundo Freitas Aragão realizou trabalhos de campo, coletou e analisou os dados, fez as fotografias e escreveu as primeiras considerações referentes ao artigo. Christian Dennys Monteiro de Oliveira supervisionou a pesquisa, organizou a apresentação das fotografias em fotopoemas, escreveu e revisou o artigo. Tiago Vieira Cavalcante contribuiu com a construção teórico-metodológica, escreveu e revisou ao artigo. 